\title{
Evaluation of Land Suitability for Selected Tree Species in the Mesozoic Highlands of Ethiopia
}

\section{Kassa Teka* and Yemane Welday}

Department of Land Resources Management and Environmental Protection, College of Dryland Agriculture and Natural Resources, Mekelle University, P.O. Box 231, Mekelle, Ethiopia (*kassateka@yahoo.com).

\begin{abstract}
This paper aimed at evaluating the potential of the different soil attributes for plantation of selected forest trees (Faidherbia albida, Eucalyptus camaldulensis and Balanitus aegiptica) dominantly grown in the northern highlands of Ethiopia. The study was conducted at Korir watershed, northern Ethiopia. The method used to evaluate the land suitability was based on the FAO approach for land evaluation for forestry. The results of the evaluation revealed that suitability classes of these trees range from highly suitable (S1) to permanently not suitable (N). Eucalyptus camaldulensis was highly suitable on the relatively gentle valley bottom and foot slope (6\% of the area) having greater soil depth while unsuitable in majority (about $58 \%$ ) of the area. Both Faidherbia albida and Balanitus aegyptiaca were suitable in more than $85 \%$ of the study area. The major limiting factors were the steep slope and shallow soil depth in major part of the area. Hence, evaluating the land potential for individual species and assigning these species based on their land requirements should be done before plantation so as to increase the trees' survival rate.
\end{abstract}

Keywords: Faidherbia albida, Eucalyptus camaldulensis, Balanitus aegiptica, Suitability, Ethiopia.

\section{INTRODUCTION}

Land degradation, which includes degradation of vegetation cover and soil, is a major environmental and economic challenge in Sub-Saharan Africa including Ethiopia (Mebrat, 2015). According to the study by Temesgen et al. (2014) in Ethiopia, land resources such as soil, water, forest trees and biodiversity are deteriorated. These authors revealed that approximately $17 \%$ of the potential agricultural Gross Domestic Product (GDP) is being lost because of soil degradation. Removal of vegetation for domestic and industrial purposes, cultivation of slopping lands to increase agricultural production area, use of crop residues and animal manure or dung as fuel were the major causes. A country level survey by the Federal Democratic Republic of Ethiopia (FDRE) in 2011 reported that the rural households of Ethiopia account for about $93 \%$ of the total energy consumption, and $99.5 \%$ of their energy comes from biomass fuels. Furthermore, the rapidly growing population (about 2.6\%) demands more land for cultivation and more energy for consumption from natural resources; the consequence will be increased deforestation. Researches (e.g. Sonneveld and Keyzer, 
2002) indicated that fertile top soil in the country was lost at a rate of one billion cubic meters per year, resulting in massive environmental degradation. Besides, only about $47 \%$ of the land area of Ethiopia falls in the category of being suitable for tree planting because of either shallowness of the soil, land steepness, severity of erosion or low soil fertility (Holden et al., 2003).

To tackle the problem, massive reforestation, afforestation, and soil and water conservation activities were launched in the country (Mehari, 2005). A study by Bekele (2011) estimated more than 972,000 hectares of state and community plantation areas in Ethiopia. Of this area, 190,000 hectares were classified as commercial plantations and the remaining were nonindustrial plantations (Bekele, 2011). Since 2007, for instance, massive tree-planting campaigns have been undertaken in connection with the celebration of the country's Millennium. Tadesse (2012) reported that about 2.21 billion seedlings were planted in 2009 in four regions (Oromia, SNNP, Amhara and Tigray) of the country. Forest trees such as Fehiderbia albida, Eucalyptus camaldulensis and Balanitus aegiptica were dominantly planted for economic and environmental conservation purposes. These trees, according to Gebreegziabher et al. (2010), supplement household's income through sales of wood products and contribute to risk aversion by increasing agricultural production and spreading risks of agricultural production collapse. These trees were planted mainly in degraded areas (Jagger and Pender, 2003) and to some extent as agroforestry systems (Kidanu et al., 2004).

Nevertheless, reforestation impacts could not match with the deforestation rates in which poor implementation and follow-up of plantations have limited their success. Re- forestation goals were set in terms of number of seedlings to be planted rather than their ecological requirements (Mehari, 2005). However, the successful growth and production of planted trees can only be sustainable if the ecological characteristics match with the requirements of the planted trees (FAO, 1995). For instance, the highland of northern Ethiopia (Tigray) has a highly diverse and complex pattern of soils resulting from the wide range of landforms, geology, climate and vegetation (Teka et al., 2015). However, tree plantations have been implemented with little due consideration of the ecological (soil attribute in particular) requirements of individual species. This has resulted to the poor trees survival rate in the area ranging from approximately $45 \%$ on village managed to approximately $65 \%$ on household managed woodlots (Gebremedhin et al., 2003). While, Jagger and Pender (2003) estimated an 
average survival rates in the region for eucalyptus at $47 \%, 58 \%$ and $71 \%$ for village level, sub-village level and private woodlots, respectively.

To overcome the challenges of poor tree seedlings survival rate, it is important to design economically feasible, socially acceptable and ecologically viable forest trees management and conservation strategies (Mebrat, 2015). Hence, any decision made on what species to plant and where to plant must be taken carefully. The mechanism by which trees are appropriately selected, arranged and managed are through land quality measurement (Venema and Vargas, 2007; Teka et al., 2010; Teka and Haftu, 2012).

\section{MATERIALS AND METHODS}

\subsection{The study area}

The study watershed is located at Korir village, in Tigray (Fig 1). The total size of the catchment is $17 \mathrm{~km}^{2}$. The mean annual rainfall is about $466 \mathrm{~mm}$ with mean annual temperature ranging from 9 to $28^{\circ} \mathrm{C}$.

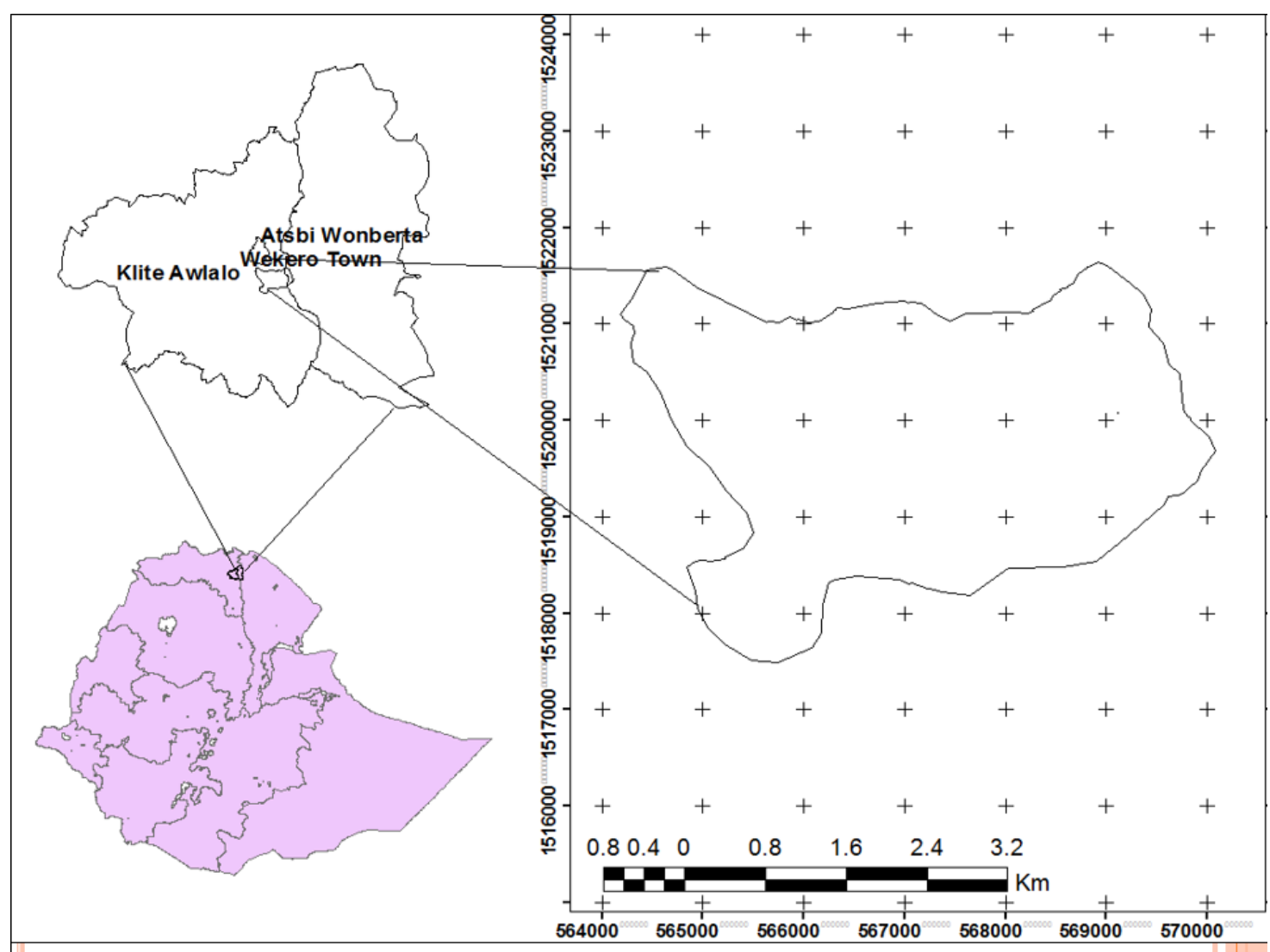

Figure 1. Location of the study area. 
The study area is covered by Mesozoic sedimentary sequence which composed of mainly four formations, arranged from bottom to top as: Adigrat Sandstone, Antalo Limestone, Agula Shale and Amba Aradam formation (Rabia et al., 2013). The major soil reference groups found in the study catchment are Regosols, Leptosols, Vertisols and Cambisols (Teka and Haftu, 2012; Rabia et al., 2013). The major land cover/land use types of the catchment are arable land, grazing land, bush and shrub land, plantation, plantation plus bush (mixed) and built-up areas (Teka and Haftu, 2012).

\subsection{Methodology}

The periphery of the catchment, landform and each land cover type were demarcated from aerial photos and topographic map $(1: 50,000)$. A preliminary reconnaissance of the catchment area was conducted prior to the detailed survey so as to distinguish the main land cover types, landforms and soil types. The above information helped to classify the entire area of the catchment into eleven land units, set of pixels characterized by the same value for the diagnostic attributes (Van Orshoven et al., 2011). These major land units helped to determine the number of pits to be excavated. A soil profile pit (of $1.5 \mathrm{~m} \times 2 \mathrm{~m}$ and up to the depth of the underlying rock) was opened in each land unit except residential areas, and described using FAO soil description guideline (FAO, 2006). Soil classification was made based on the world reference base for soil resources (FAO, 2014).

In total, eighteen soil samples were taken from the demarcated soil horizons for analysis of soil texture, soil $\mathrm{pH}, \mathrm{CaCO}_{3}$, soil organic carbon $(\%)$, soil $\mathrm{EC}(\mathrm{cmol}+/ \mathrm{kg}$ of soil), soil Cation Exchange Capacity (CEC), soil total Nitrogen and soil Available phosphorous. The soil samples were air-dried, gently crushed and passed through $2 \mathrm{~mm}$-sieves to obtain fine earth separates. Particle size distribution was determined by hydrometer method following pretreatment with $\mathrm{H}_{2} \mathrm{O}_{2}$ to remove organic matter, and dispersion aided by sodium hexametaphosphate. Electrical conductivity $(\mathrm{dS} / \mathrm{m})$ and soil $\mathrm{pH}\left(\mathrm{H}_{2} \mathrm{O}\right)$ were determined at a soil/water ratio of $1: 2.5$. Organic carbon (\%) was determined by the wet combustion procedure of modified Walkley Black method. The cation exchange capacity (CEC, cmol $(+) / \mathrm{kg}$ ) was determined by saturation with NH4OAc (Ammonium Acetate) at $\mathrm{pH} 7$ and subsequent replacement of $\mathrm{NH}_{4}$ by $\mathrm{NaCl}$ extraction. The free $\mathrm{CaCO}_{3}$ content (\%) of the soils was also determined by acid neutralization method. Total nitrogen (TN) was measured by micro-Kjeldahl digestion procedure and available phosphorus $(\mathrm{P})$ by Olsen method. 
The FAO approach for land evaluation for forestry (FAO, 1984) was adopted to evaluate the land suitability for the selected trees species. The trees under study were selected based on their merits taking the economic, social and environmental context into consideration. According to these criteria, three tree species were chosen for the analysis: Eucalyptus camaldulensis, Fehiderbia albida and Balanites aegyptiaca. These tree species were evaluated against the geomorphology (slope) and the soil (drainage, depth, $\mathrm{pH}$, salinity, coarse fragments and texture) parameters of the study area. The evaluation was done for each species and land unit following equation proposed by FAO (1984):

$$
\text { Score }=\frac{\left[\sum(\text { value } *(\text { weight }>1))\right]}{\sum(\text { weight }>1)} * \sum(\text { value } *(\text { weight }=1))
$$

This score was converted to a suitability class (Table 1). The suitability class obtained for each land unit and species was used to summarize the land unit according to the importance of the facet it belongs.

Table 1. Suitability classes.

\begin{tabular}{|lll|}
\hline Score & Suitability classes & Description \\
\hline$>0.8$ & S1 (Highly Suitable) & $\begin{array}{l}\text { Land having no, or insignificant limitations to the } \\
\text { given type of use }\end{array}$ \\
\hline $.6-0.8$ & S2 (Moderately Suitable) & $\begin{array}{l}\text { Land having minor limitations to the given type of } \\
\text { use }\end{array}$ \\
\hline $0.3-0.6$ & S3 (Marginally Suitable) & $\begin{array}{l}\text { Land having moderate limitations to the given type } \\
\text { of use }\end{array}$ \\
\hline$<0.3$ & N (Unsuitable) & $\begin{array}{l}\text { Land having severe limitations that preclude the } \\
\text { given type of use }\end{array}$ \\
\hline
\end{tabular}

\section{RESULTS AND DISCUSSION}

\subsection{Landscape units}

As explained in the earlier section, eleven landscape units were delineated for the study watershed (Fig 2).

Land Unit - 1: is situated on the plateau with a slope range of 2-5\%. The area is characterized by sheet and rill erosion; some (scattered) bushes such as Aloe succotrina, Juniperus procera, Olea europaea subsp. Africana and Rumex nervosus; 40-50\% stone cover; about $25 \%$ rock outcrop. The land was used for livestock grazing; having an average soil depth of $23 \mathrm{~cm}$ and lime stone parent material. 
Land Unit - 2: is situated on the plateau with a slope range of 2-5\%. The area is characterized by sheet, rill and gully erosion; some (scattered) bushes such as Aloe succotrina, Juniperus procera, Olea europaea subsp. Africana and Rumex nervosus; Terraced/soil faced stone bund with trench; $30-50 \%$ stone cover; about $25 \%$ rock outcrop; the land was used for rain-fed agriculture having an average soil depth of $29 \mathrm{~cm}$ and sandstone parent material.

Land Unit - 3: is situated on the side slope (hill) with a slope range of 30-50\%. The area is characterized by sheet, rill and gully erosion; < 15\% stone cover; < 15\% rock outcrop; with dense bush such as Aloe succotrina, Juniperus procera, Olea europaea subsp. Africana, Rumex nervosus, Dodonaea angustifolia and Euclea schimperi; Bush land (exclosure) having an average soil depth of $33 \mathrm{~cm}$ and sandstone parent material.

Land Unit - 4: is situated on the plateau with a slope range of 2-5\%. The area is characterized by sheet and rill erosion; $<15 \%$ stone cover; about <15\% rock outcrop; dense bush of Aloe succotrina, Juniperus procera, Olea europaea subsp. Africana, Rumex nervosus, Dodonaea angustifolia and Euclea schimperi; having an average soil depth of 28 $\mathrm{cm}$ and sand stone parent material.

Land Unit - 5: is situated at the foot slope with a slope range of 3-8\%. The area is characterized by sheet, rill and gully erosion; $15-30 \%$ stone cover; about $25 \%$ rock outcrop; livestock grazing area with scattered trees of Euclea schimperi, Acacia etbaica and Acacia seyal; having an average soil depth of $37 \mathrm{~cm}$ and sandstone parent material.

Land Unit - 6: is situated at the side slope (hilly) with a slope range of 30-50\%. The area is characterized by rill and gully erosion; stone terraced with trench bund; 30-50\% stone cover; 15-30\% rock outcrop; Planted with Acacia saligna, Eucalyptus camaldulensis, Grevillea robusta, Balanites aegyptiaca and Opuntia ficus-indica; plantation area having an average soil depth of $22 \mathrm{~cm}$ and sandstone parent material.

Land Unit - 7: is situated at the side slope (hilly) with a slope range of $30-50 \%$. The area is characterized by rill and gully erosion; stone terraced; $30-50 \%$ stone cover; $15-30 \%$ rock outcrop; naturally grown moderately dense bushes enriched with plantations of Acacia saligna, Eucalyptus camaldulensis, Grevillea robusta, Balanites aegyptiaca and Opuntia ficus-indica having a soil depth of $24 \mathrm{~cm}$ and sandstone parent material.

Land Unit - 8: is situated at the foot slope with a slope range of 3-8\%. The area is characterized by sheet and rill erosion; soil faced stone bund with trenches; 30-50\% stone (C) CNCS, Mekelle University 
cover; no rock outcrop; no trees are left; rainfed agriculture having a soil depth of $55 \mathrm{~cm}$ and lime stone parent material.

Land Unit - 9: is situated at the valley bottom with a slope range of 3-8\%. The area is characterized by sheet erosion; <15\% stone cover; no rock outcrop; some scattered trees of Faidherbia albida; rainfed agriculture having a soil depth of $>150 \mathrm{~cm}$ and sand stone parent material.

Land Unit - 10: is situated at the valley bottom with a slope range of 3-8\%. The area is characterized by sheet erosion; <15\% stone cover; no rock outcrop; few trees of Faidherbia albida; irrigated agriculture having a soil depth $>150 \mathrm{~cm}$ and sand stone parent material.

Land Unit - 11: is situated at the foot slope with a slope range of 8-15\%. The area is dominated by lime stone parent material and is used for settlement. Opuntia ficus-indica and Eucalyptus cameldulensis are the plant species planted on this land unit.

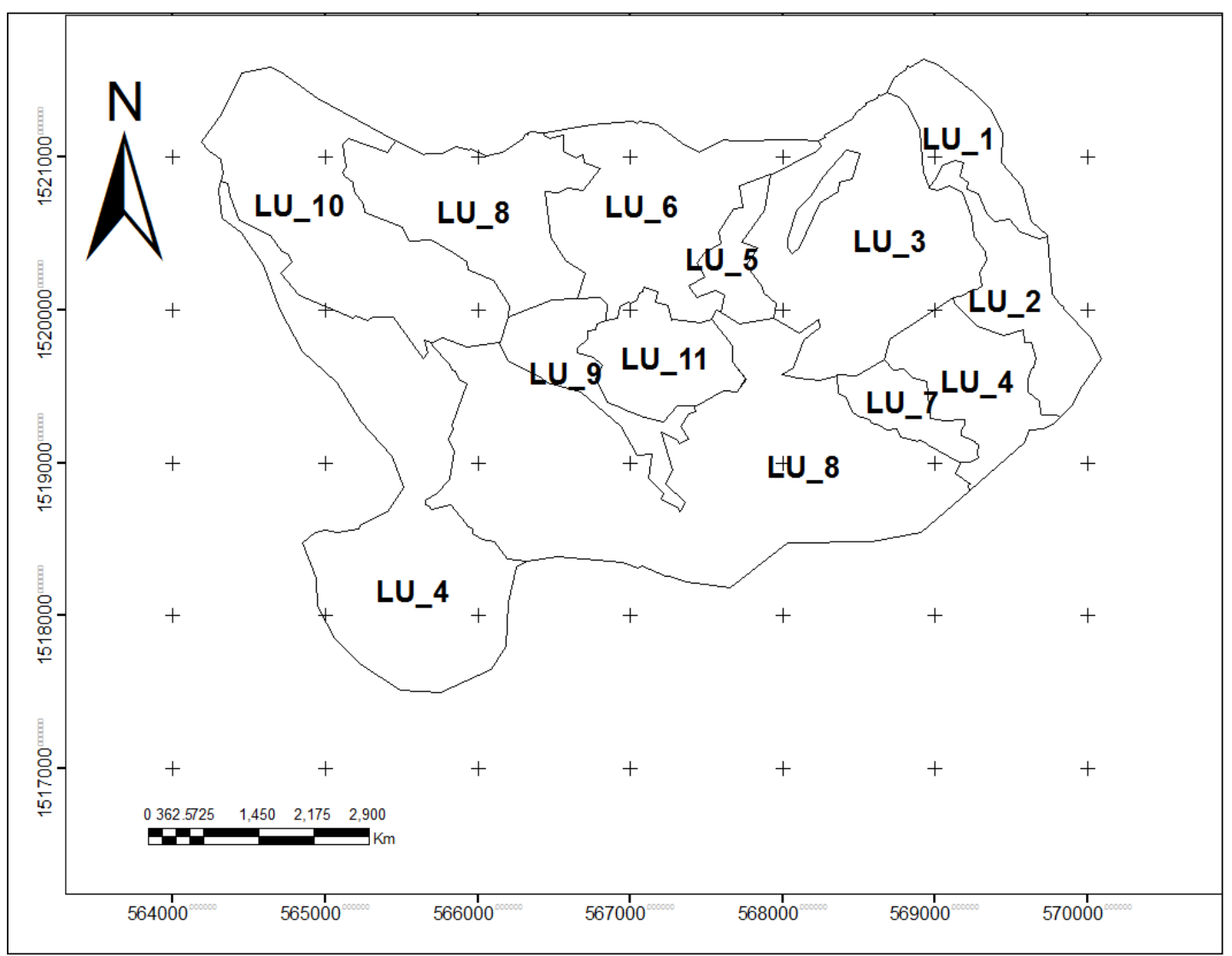

Figure 2. Land unit map of Korir area.

\subsection{Description of soil physical and chemical properties}

The major soil reference groups with their physical and chemical properties are shown in 
table 2. The study revealed that rooting depth in most soil reference groups of the study area is very shallow to moderately shallow based on the classification guideline developed by FAO (2006). This land quality appears to be of limited value for the trees in question. According to Van Gool (2005), any soil less than $50 \mathrm{~cm}$ deep is considered unsuitable for most perennial crops, while soils having in excess of $80 \mathrm{~cm}$ depth are preferable. The EC $(\mathrm{dS} / \mathrm{m})$ values of the soils are very low, ranging from 0.1 to 0.3 , according to the Hunting (1976) classification guide. Based on the findings of Herrera (2000), when the electrical conductivity is less than 2 , few salinity problems are evident. The $\mathrm{pH}$ of the soil, range between 6.9 and 8.2, is within the neutral to slightly alkaline $\mathrm{pH}$ rating following the Hunting (1976) and Van Gool (2005) classification guidelines. The $\mathrm{pH}$ of most soils in the area is ideal to grow most crops including the trees in question. According to Herrera (2000), most crops grow satisfactorily on soils with a $\mathrm{pH}$ ranging from 6.2 to 8.3. The textural class of the soil reference groups in the study watershed range from sand to clay loam, which are characterized by a good to fair soil workability (Van Gool, 2005). The $\mathrm{CaCO}_{3}(\%)$ content is classified as high to very high while the CEC values range from very low to very high content (Hunting, 1976).

Table 2. Soil physical and chemical properties.

\begin{tabular}{|c|c|c|c|c|c|c|c|c|c|c|}
\hline $\boldsymbol{L U}$ & $\begin{array}{l}\text { Depth } \\
(\mathrm{cm})\end{array}$ & $\begin{array}{l}E C \\
(d S / m)\end{array}$ & $p H$ & $\begin{array}{l}\text { Textural } \\
\text { class }\end{array}$ & $\begin{array}{l}T N \\
(\%)\end{array}$ & $\begin{array}{l}\mathrm{CaCO}_{3} \\
(\%)\end{array}$ & $\begin{array}{l}\text { Pava } \\
\text { (ppm) }\end{array}$ & $\begin{array}{l}O M \\
(\%)\end{array}$ & $\begin{array}{l}C E C \\
(\mathrm{Cmol} / \mathrm{kg})\end{array}$ & Soil Type \\
\hline 1 & $0-23$ & 0.26 & 7.41 & Loam & 0.2 & 8.90 & 4.25 & 4.26 & 30.96 & $\begin{array}{l}\text { Calcaric } \\
\text { Leptosol }\end{array}$ \\
\hline 2 & $0-29$ & 0.10 & 7.03 & Sand & 0.02 & 7.68 & 3.61 & 1.44 & 2.7 & $\begin{array}{l}\text { Calcaric } \\
\text { Leptosol }\end{array}$ \\
\hline 3 & $0-28$ & 0.09 & 7.04 & $\begin{array}{l}\text { Sandy } \\
\text { clay }\end{array}$ & 0.035 & 8.495 & 1.815 & 1.715 & 11.16 & $\begin{array}{l}\text { epi Leptic } \\
\text { Cambisol }\end{array}$ \\
\hline 4 & $0-33$ & 0.26 & 7.9 & $\begin{array}{l}\text { Sandy } \\
\text { loam }\end{array}$ & 0.345 & 9.905 & 7.58 & 7.665 & 23.85 & $\begin{array}{l}\text { epi Leptic } \\
\text { Cambisol }\end{array}$ \\
\hline 5 & $0-37$ & 0.065 & 6.93 & $\begin{array}{l}\text { Sandy } \\
\text { loam }\end{array}$ & 0.05 & 7.885 & 1.77 & 1.975 & 6.75 & $\begin{array}{l}\text { endoleptic } \\
\text { Regosol } \\
\end{array}$ \\
\hline 6 & $0-22$ & 0.18 & 8.05 & $\begin{array}{l}\text { Sandy } \\
\text { clay }\end{array}$ & 0.15 & 12.54 & 6.34 & 3.77 & 13.14 & $\begin{array}{l}\text { calcaric } \\
\text { Leptosol }\end{array}$ \\
\hline 7 & $0-24$ & 0.225 & 8.01 & $\begin{array}{l}\text { Clay } \\
\text { loam }\end{array}$ & 0.31 & 21.03 & 8.56 & 8.16 & 38.34 & $\begin{array}{l}\text { epi Leptic } \\
\text { Cambisol }\end{array}$ \\
\hline 8 & $0-55$ & 0.23 & 8.2 & $\begin{array}{l}\text { Sandy } \\
\text { clay }\end{array}$ & 0.1 & 26.29 & 3.655 & 3.12 & 26.01 & $\begin{array}{l}\text { endoleptic } \\
\text { Regosol }\end{array}$ \\
\hline 9 & $0-150$ & 0.067 & 7.980 & $\begin{array}{l}\text { Sandy } \\
\text { loam }\end{array}$ & 0.030 & 8.763 & 3.980 & 1.143 & 6.600 & Regosol \\
\hline 10 & $0-150$ & 0.287 & 8.223 & $\begin{array}{l}\text { Clay } \\
\text { loam }\end{array}$ & 0.060 & 11.593 & 1.060 & 2.620 & 43.740 & $\begin{array}{l}\text { Calcaric } \\
\text { Vertisol }\end{array}$ \\
\hline
\end{tabular}




\subsection{Land suitability for forest trees plantations}

Table 3 shows the suitability results of the selected three species, i.e. Eucalyptus camaldulensis, Faidherbia albida, and Balanites aegyptiaca. The suitability classes for these trees range from highly suitable $(\mathrm{S} 1)$ to permanently not suitable $(\mathrm{N})$. This is due to the different conditions the trees require for their developments in the local area in question (Mehari, 2005; Venema and Vargas, 2007; Teka and Haftu, 2012).

Table 3. Provisional land suitability classification for trees plantation.

\begin{tabular}{|llll|}
\hline Land units & \multicolumn{3}{c|}{ Tree species } \\
\cline { 2 - 4 } & Eucalyptus camaldulensis & Faidherbia albida & Balanites aegyptiaca \\
\hline LU_1 & S3 & S3 & S1 \\
\hline LU_2 & S3 & S3 & S1 \\
\hline LU_3 & N & S3 & S1 \\
\hline LU_4 & S2 & S3 & S1 \\
\hline LU_5 & S1 & S3 & S1 \\
\hline LU_6 & N & N & S3 \\
\hline LU_7 & N & N & S3 \\
\hline LU_8 & N & S3 & S1 \\
\hline LU_9 & S1 & S2 & S1 \\
\hline LU_10 & S2 & S3 & S1 \\
\hline
\end{tabular}

\subsection{Land Suitability for Eucalyptus camaldulensis}

Eucalyptus camaldulensis (locally called keyih kalamintos) is widely grown in most parts of Ethiopia including the study area for both domestic and industrial purposes (Getahun, 2002). According to Getahun (2002), about 506,000 ha of the total plantation area, equivalent to 52\%, was occupied by Eucalyptus. A field assessment from Huruta district (Ethiopia) also showed that about $80 \%$ of the farming households have planted Eucalyptus (Mekonnen, 2010). The tree is used mainly for poles, posts, construction timber, fuel-wood, ornamental, shade, bee forage, windbreak and swamp reclamation as it tolerates water logging (Oballa et al., 2010).

Benefit-cost analysis based on community and village level survey data from Tigray (Ethiopia) illustrates that planting eucalyptus yields high rates of return, well above $20 \%$ in most circumstances (Jagger and Pender, 2003). A similar study by Mekonnen et al. (2007) has shown that income from Eucalyptus sales contributes on average up to $25 \%$ of total household's annual cash income, and for poor households up to $72 \%$ of the total annual cash income. Another study from Huruta district (Ethiopia) showed that Eucalyptus wood products 
contributed to $78 \%$ of the local market economy for firewood, $100 \%$ each for construction poles and posts, and 20\% for charcoal (Mekonnen, 2010). A similar study in Ethiopia has also reported that Eucalyptus contributed to $92 \%$ construction poles, $74 \%$ timber, $85 \%$ firewood, $40 \%$ charcoal, $83 \%$ posts and $91 \%$ farm implements for rural livelihoods (Mekonnen et al. 2007).

Despite the apparent benefits, there have also been public reactions against Eucalyptus camaldulensis planting. The tree is known to cause a number of environmental hazards like depletion of groundwater, dominance over other species by allelopathic effects, loss of soil fertility and negative impacts on local food security issues (Joshi and Palanisami, 2011). A study on the effect of the tree on yield of two major crops (Zea mays and Panicum miliaceum) showed a reduction as the result of the tree stand (Alebachew et al., 2015). These authors revealed that Maize grain yield reduction was recorded around 6.6 fold as compared to the control (20 m distance from tree stand). Whereas, Finger millet grains yield difference was around 2.9 fold as compared to the control. Another study on the impact of growing Eucalyptus on ground water level indicated that 20 years of continuous cultivation of Eucalyptus in private and public lands reduced the water level in freshly dug bore wells to $260 \mathrm{~m}$ as compared to the mean depth of water level in bore wells (177 m) (Joshi and Palanisami, 2011). These authors also revealed that the bore well yields, located within a distance of $1 \mathrm{Km}$ from Eucalyptus plantations, were reduced by 35 to 42 percent during the span of 3-5 years; whereas, for bore wells located at distance of 1-3 Km from such plantations, the reduction was to the tune of 25 to 37 percent.

The findings from the study watershed revealed that Eucalyptus camaldulensis was highly suitable (S1) on both the rain-fed cultivation at the valley bottom and grazing land at the foot slope (which is $6 \%$ of the area). The tree was marginally suitable (S3) in both grazing and rainfed cultivated lands at the plateau (7\% of the total area), and was moderately suitable (S2) on bush land at the plateau, and irrigated land at the valley bottom (28.53\% of the total area). Nevertheless, the tree was unsuitable in the steep areas and the shallow cultivated land at the foot slope $(58.07 \%$ of the total area). It can be concluded that the tree was suitable only in $41.53 \%$ of the study area (Table 3 and Fig 3 ) regardless of its actual plantation in majority of the area. The major factors which limit the suitability of the area for the tree were the steep slope $(30-50 \%)$, limited soil depth $(<33 \mathrm{~cm})$ and higher stone cover $(30-50 \%)$ in majority of the study area.

(C) CNCS, Mekelle University 


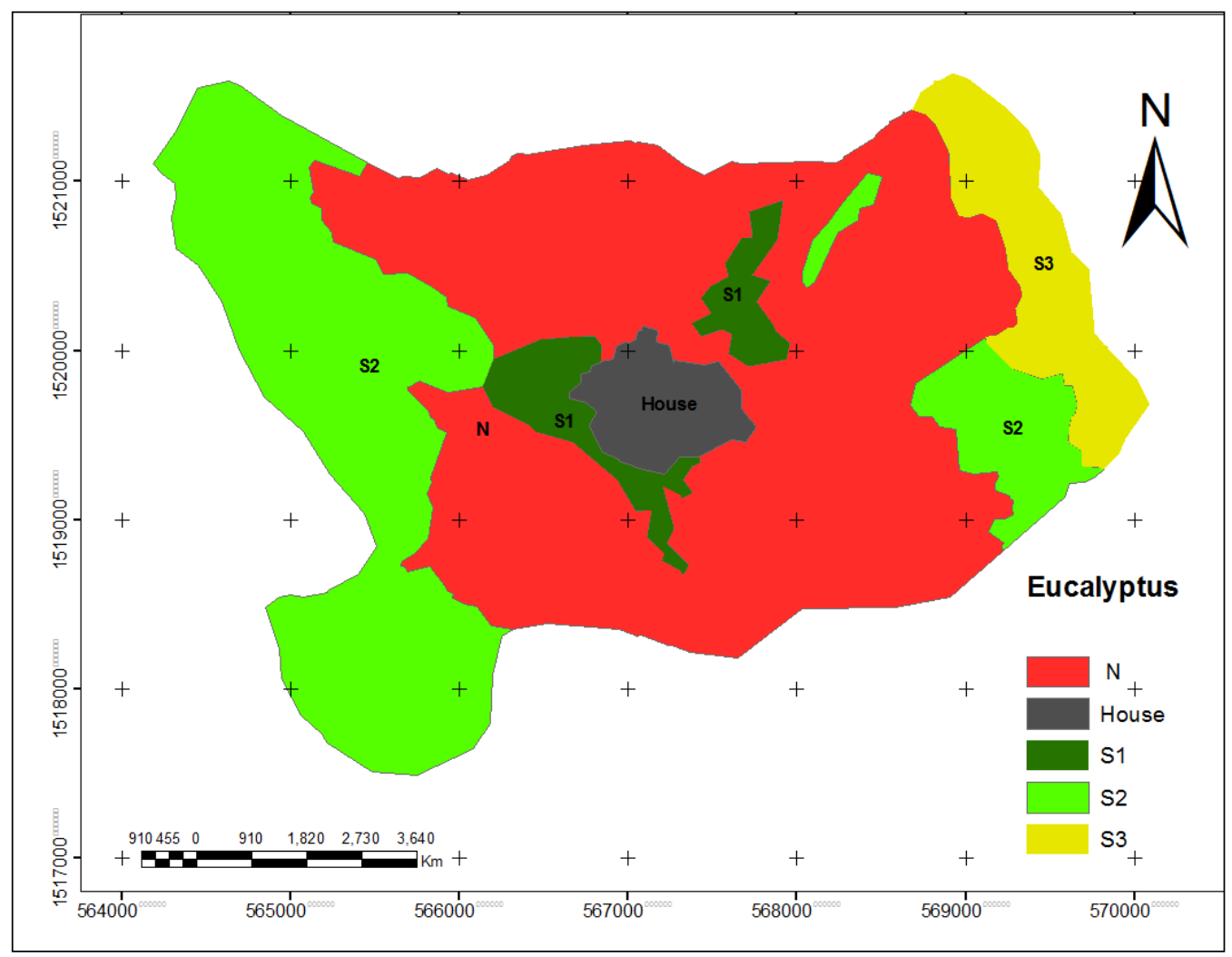

Figure 3. Suitability map for Eucalyptus camaldulensis.

\subsection{Land suitability for Faidherbia albida}

Faidherbia albida (locally named 'Momena') is another widely planted and naturally grown tree in Ethiopia, and in particular the northern part. The tree is used by the community for firewood, charcoal, timber (construction), farm tools, fodder (pods, leaves), nitrogen fixation, shade, windbreak and fence (cut branches).

The study indicated that Faidherbia albida is suitable (S2 and S3) in $80.88 \%$ of the study area (Table 3 and Fig. 4). It is moderately suitable (S2) in 3.53\%, marginally suitable (S3) in $77.35 \%$ and unsuitable $(\mathrm{N})$ in $19.12 \%$ of the study area. There was no soil classified as highly suitable (S1).

A similar study was also reported in Somalia by Venema and Vargas (2007), in which 68.5\% of the land area was un-suitable $(\mathrm{N}), 30.4 \%$ marginally suitable (S3) and $1.1 \%$ moderately suitable (S2). However, there was no any portion of land classified as highly suitable (S1) for the tree. The major factors which limit the suitability of the area for the tree were the steep slope (30-50\%), limited soil depth $(<33 \mathrm{~cm})$ and higher stone cover $(30-50 \%)$ in major part of the study area. 


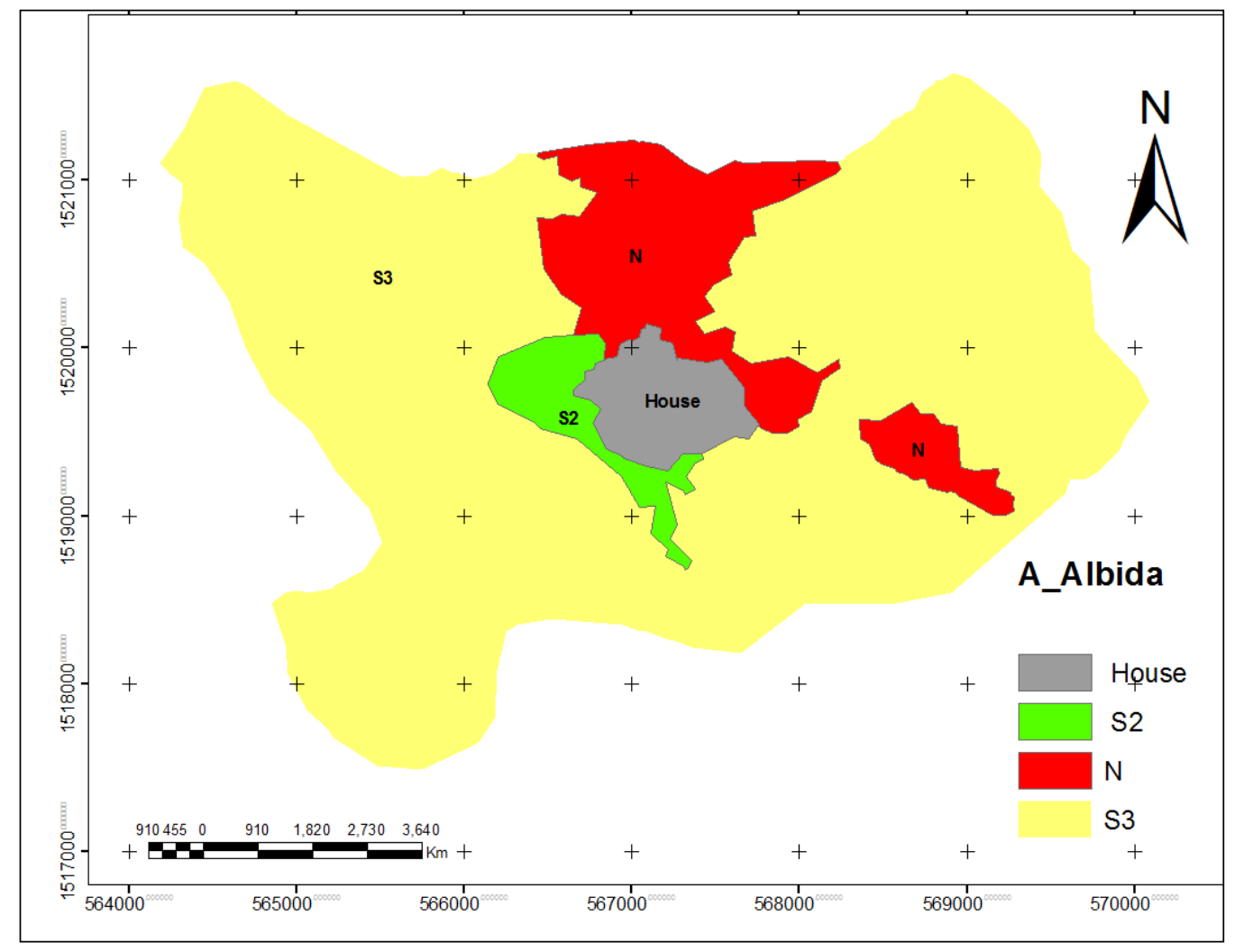

Figure 4. Suitability map for Faidherbia albida.

\subsection{Land suitability for Balanites aegyptiaca}

Balanitus aegyptiaca (locally named ' $n d r u r ')$ is one of the dominant tree species deliberately retained on farm fields in the Tigray region of Ethiopia (Gebrehiwet, 2004). It is used by the community of the study area for fodder (shoots and fruit), as agroforestry tree, for firewood, charcoal, poles, farm tools, shade, windbreak and fencing (cut branches).

The study showed that the tree was suitable (100\%) in the whole area. It was highly suitable (S1) in most part of the study area (80.88\%) except land units coded 6 and 7 (19.12\% of the study area) which were marginally suitable (Fig. 5 and Table 3). In contrast, a similar study in Somalia by Venema and Vargas (2007) showed that majority (68.5\%) of the area was unsuitable (N) for Balanites aegyptiaca. Only 31.5\% (16.1\% S3 and 15.4\% S2) was suitable. However, there was no any portion of land classified as highly suitable (S1) for the tree (Venema and Vargas, 2007). The major factors which limit the suitability of the area for the tree are the steep slope $(30-50 \%)$, limited soil depth $(<33 \mathrm{~cm})$ and higher stone cover $(30-$ $50 \%$ ) in majority of the study area. 


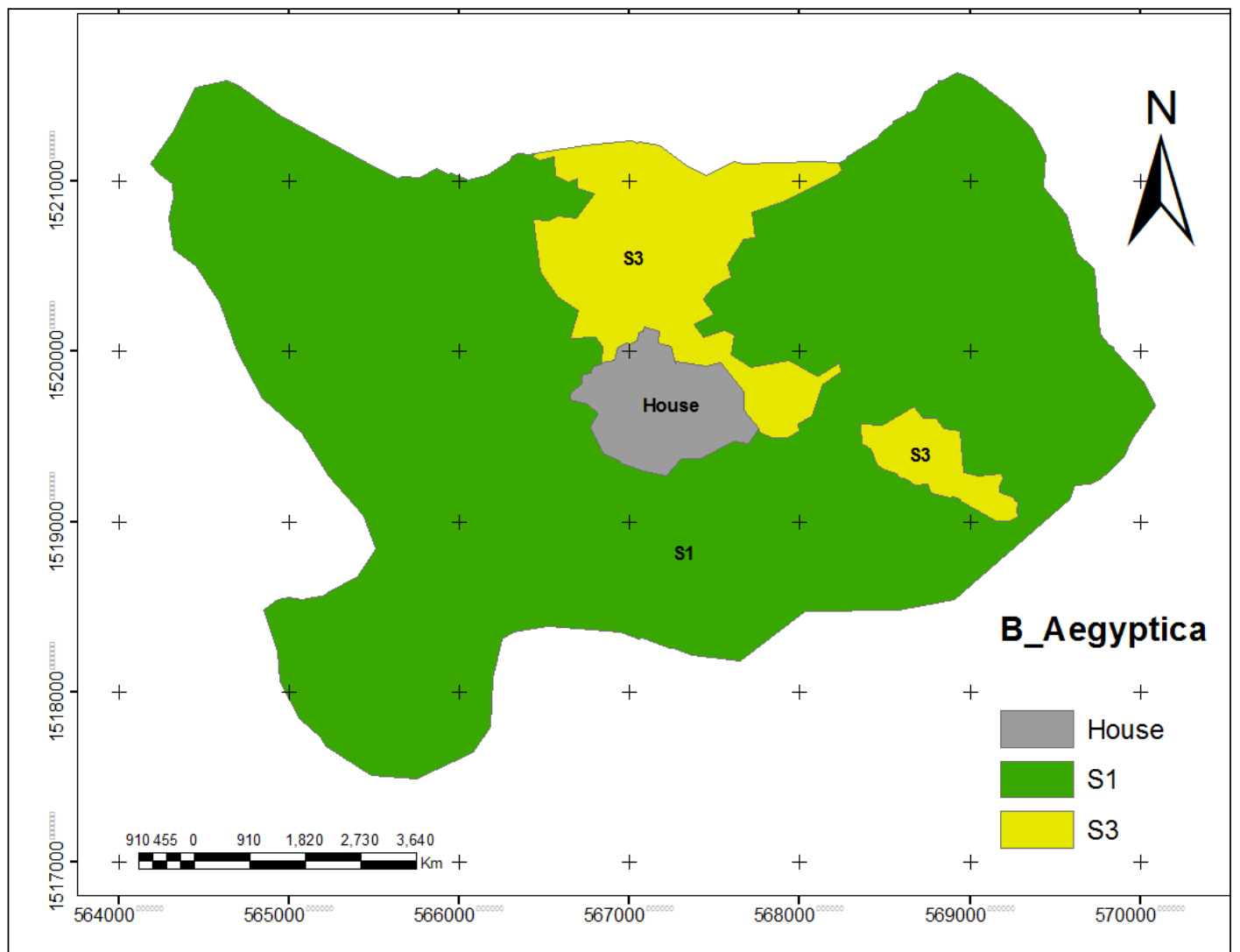

Figure 5. Suitability map for Balanites aegyptiaca.

\section{CONCLUSIONS}

The Korir watershed contains six soil reference groups, i.e. Regosol, calcaric Leptosol, calcaric Vertisol, epileptic Cambisol, endoleptic Cambisol and epileptic Regosol. The rooting depth is very shallow to moderately shallow in most of these soils, which appeared to be of limited value for the deep rooted perennial plants (Eucalyptus camaldulensis, Faidherbia albida, and Balanites aegyptiaca) considered in this study. Moreover, the $\mathrm{CaCO}_{3}(\%)$ content was classified as high to very high for plant growth which can also influence the successful growth and production of the trees under study.

The suitability class of the area for the studied trees' ranges from highly suitable (S1) to permanently not suitable $(\mathrm{N})$. Eucalyptus camaldulensis, the most common tree species for community woodlots and private tree investments in northern Ethiopia, was highly suitable (S1) on the relatively gentle valley bottom and foot slope (6\% of the area) having greater soil depth; marginally suitable (S3) in the shallow degraded upland soils (7\% of the area); moderately suitable (S2) at the relatively undisturbed upland and clay dominated soils in the 
valley bottom (28.53\% of the area); unsuitable in the steep areas having a very shallow soil depth $(58.07 \%$ of the study watershed). Faidherbia albida, one of the dominant tree species deliberately retained on farm fields in the Tigray region of Ethiopia, was suitable (S2 and S3) in about $80.9 \%$ of the study area. In contrary to the other trees, Balanitus aegyptiaca was suitable (S1, S2, and S3) in the whole (100\%) area.

It can be concluded that Eucalyptus camaldulensis was unsuitable in majority of the study area. Its potential productivity was limited to the gentle slope areas with deep soils. Rather, both Faidherbia albida and Balanites aegiyptica were suitable in larger part though they also prefer more gentle slope and deep soils. Therefore, evaluating the land potential for individual species and assigning these species based on their land requirements before plantation can help sustain the production of the land and the tree species in question. Moreover, reducing slope gradient and increasing soil depth to the required level through prior implementation of soil and water conservation measures can help increase the potential growing area for the trees.

\section{ACKNOWLEDGEMENTS}

Our particular gratitude goes to the Mekelle University NORAD II Project for the financial and logistics support. The authors would also like to thank the farmers and Korir village administration for providing us valuable information.

\section{REFERENCE}

Alebachew, M., Amare, T \& Wendie, M. 2015. Investigation of the Effects of Eucalyptus camaldulensis on Performance of Neighbouring Crop Productivity in Western Amhara, Ethiopia. Open Access Library Journal, DOI:10.4236/oalib.1100992, 2: e992.

Bekele, M. 2011. Forest Plantations and Woodlots in Ethiopia: a platform for stakeholders in African Forestry. African Forest Forum Working Paper Series, volume 1, issue 12, Nairobi, Kenya, 56p.

FAO. 1984. Guidelines: Land evaluation for forestry. FAO Soils Bulletin, No. 48, Rome, $123 \mathrm{p}$.

FAO. 1995. Planning for sustainable use of land resources towards a new approach. FAO land and water Bulletin 2. Food and Agricultural organizations of the United Nations, Viale delle Terme di Caracalla, 00100 Rome, Italy.

(c) CNCS, Mekelle University 228

ISSN: $2220-184 X$ 
FAO. 2006. Guidelines for soil description (Fourth Edition). Food and Agriculture Organization of the United Nations, Rome, 109p.

FAO. 2014. World reference base for soil resources. A framework for international classification, correlation and communication. World Soil Resources Reports 103. Food and Agriculture Organization of the United Nations, Rome, 145p.

Federal Democratic Republic of Ethiopia (FDRE). 2011. Ethiopia's Climate-Resilient Green Economy Strategy; Federal Democratic Republic of Ethiopia: Addis Ababa, Ethiopia. pp. 4-44.

Gebreegziabher, Z., Mekonnen, A., Kassie, M \& Köhlin, G. 2010. Household Tree Planting in Tigrai, Northern Ethiopia: Tree Species, Purposes, and Determinants. Environment for Development, Discussion Paper Series, EfD DP, 10-01, 30p.

Gebrehiwet, K. 2004. The development of Agro forestry in the dry lands of Ethiopia. Paper presented in the dry lands agroforestry workshop, 1-3 September 2004, Nairobi, Kenya, pp. 1-45.

Gebremedhin, B., Pender, J., Ehui, S.K \& Haile, M. 2003. Policies for Sustainable Land Management in the Highlands of Tigray, northern Ethiopia: Summary of papers and proceedings of a workshop held at Axum Hotel, Mekelle, Ethiopia, 28-29 March 2002. Socio-economics and Policy Research Working Paper 54. International Livestock Research Institute, Nairobi, Kenya, ISBN 92-9146-138-5, 75p.

Getahun, A. 2002. Eucalyptus Farming in Ethiopia: The Case for Eucalyptus Woodlots in the Amhara Region. In: 2002 Bahir Dar Conference Proceedings, Ethiopian Society of Soil Science, Bahir Dar, 137-153.

Herrera, E. 2000. Soil Test Interpretations: Guide A-122. Cooperative Extension Service, College of Agriculture and Home Economics, New Mexico State University, 4p.

Holden, S., Benin, S., Shiferaw, B \& Pender, J. 2003. Tree Planting for Poverty Reduction in Less favored Areas of the Ethiopian Highlands. Small-scale Forest Economics, Management and Policy, 2(1): 63-80.

Hunting. 1976. Tigray Rural Development Report. Hemel Hempstead, Hertfordshire, UK: Hunting Technical Service. Int, Wallingford, England.

Jagger, P \& Pender, J. 2003. The role of trees for sustainable management of less favored lands: the case of eucalyptus in Ethiopia. Forrest Policy and Economics, 5: 83-93. 
Joshi, M \& Palanisami, K. 2011. Impact of Eucalyptus Plantations on Ground Water Availability in South Karnataka. ICID $21^{\text {st }}$ International Congress on Irrigation and Drainage, 15-23 October 2011, Tehran, Iran, R.57.4.03, 255-262.

Kidanu, S., Mamo, T. \& Stroosnijder, L. 2004. Eucalyptus-wheat interaction on Ethiopian Nitosols. Agricultural Systems, 80: 151-170.

Mebrat, W. 2015. Natural Regeneration Practice in Degraded High Lands of Ethiopia through Area Enclosure. International Journal of Environmental Protection and Policy, 3(5): 120-123.

Mehari, A. 2005. Growth and suitability of some tree species selected for planting in adverse environments in Eritrea and Ethiopia. PhD thesis, Swedish University of Agricultural Sciences, Uppsala. SSN 1652-6880, ISBN 91-576-6990-2.

Mekonnen, Z. 2010. Community Opinion, Marketing and Current Debates on Eucalyptus in Huruta District, Arsi Zone of Oromia Region, Ethiopia. In: Gil L, Tadesse W, Tolosana E \& López R, Eds. Eucalyptus Species Management, History, Status and Trends in Ethiopia. Proceedings from the Congress held in Addis Ababa. September $15^{\text {th }}-17^{\text {th }}, 2010$, pp $131-145$.

Mekonnen, Z., Habtemariam, K., Mulugeta, L \& Campbell, B. 2007. The role and management of Eucalyptus in Lode Hetosa District, Central Ethiopia. Forests, Trees and Livelihoods, 17(4): 309-323.

Oballa, P.O., Konuche, P.K.A., Muchiri, M.N \& Kigomo, B.N. 2010. Facts on Growing and Use of Eucalyptus in Kenya. Kenya Forestry Research Institute, Nairobi, Kenya. ISBN: $9966-7458-1-5$.

Rabia, A., Afifi, R.R., Aweke Mulualem, Bianchi, S., Figuredo, H., Huong, T.L., Lopez, A.A., Mandala, S.D., Matta, E., Ronchi, M., Solomon Hishe, Tine, A.K., Youssef, M.S., Gutirrez, M.G., Yusuf, M.M \& Alessandro, V. 2013. Soil Mapping and Classification: a case study in the Tigray region, Ethiopia. Journal of Agriculture and Environment for International Development, 107(1): 73-99.

Sonneveld, B.G.J.S \& Keyzer, M.A. 2002. Land under pressure: soil conservation concerns and opportunities for Ethiopia. Land Degradation and Development, 14(5): 5-23.

Tadesse, W. 2012. The status of forestry development in Ethiopia: Challenges and Opportunities. National Dialog on Sustainable Agricultural Intensification in Ethiopia 
and its role on the climate resilient green economy initiative in Ethiopia. July 23rd and 24th, 2012, ILRI Campus, Addis Ababa.

Teka, K \& Haftu, M., 2012. Land Suitability Characterization for Crop and Fruit Production in Midlands of Tigray, Ethiopia. Momona Ethiopian J Science, 4(1): 64-76.

Teka K., Van Rompaey, A \& Poesen J. 2010. Land Suitability Assessment for Different Irrigation Methods in Korir Watershed, Northern Ethiopia. Journal of the Drylands, 3(2): 214-219.

Teka, K., Van Rompaey, A., Poesen, J., Van Bruyssel, S., Deckers, J., \& Amare, K. 2015. Spatial Analysis of Land Cover Changes in Eastern Tigray (Ethiopia) from 1965 to 2007: are there signs of a Forest Transition? Land Degradation and Development, 26: 680-689.

Temesgen, G., Amare, B \& Hagos, G. 2014. Land Degradation in Ethiopia: Causes, impacts and rehabilitation techniques. Journal of Environment and Earth Science, 4(9): 98104.

Van Gool, D., Tille, P \& Moore, G. 2005. Land Evaluation Standards for Land Resource Mapping (Third edition). Assessing Land Qualities and Determining Land Capability in South-Western Australia. Resource Management Technical Report 298. ISSN 1039-7205.

Van Orshoven, J., Kint, V., Wijffels, A., Estrella, R., Bencsik, G., Vanegas, P., Muys, B., Cattrysse D \& Dondeyne, S. 2011. Upgrading Geographic Information Systems to Spatial decision Support Systems. Mathematical and Computational Sciences Forestry and Natural-Resource Sciences, 3(1): 36-41.

Venema, J.H \& Vargas, R.R. 2007. Land Suitability Assessment of a Selected Study Area in Somaliland. FAO-SWALIM Technical Project Report L-06. Nairobi, Kenya. 